\title{
SIMULATION OF Si AND GaAs SUBMICRON TRAPATT DIODES
}

\author{
J. Vyšniauskas and J. Matukas \\ Faculty of Physics, Vilnius University, Sauletekio 9, LT-10222 Vilnius, Lithuania \\ E-mails: juozas.vysniauskas@ff.vu.lt; jonas.matukas@ff.vu.lt
}

Received 2 February 2014; revised 27 March 2014; accepted 29 May 2014

\begin{abstract}
Plasma formation and extraction processes in submicron silicon $\mathrm{N}^{+} \mathrm{NP}^{+}, \mathrm{GaAs} \mathrm{N}^{+} \mathrm{NP}^{+}$, and GaAs NM Schottky TRAPATT (TRApped Plasma Avalanche Triggered Transit) diodes were simulated. The simulation of GaAs TRAPATT diodes was done for the first time. The quasi-hydrodynamic model was chosen for the simulation of the processes. The Synopsys TCAD Sentaurus Software Package was used. The carrier mobility dependence on phonon scattering, impurity scattering, carrier-carrier scattering, intervalley scattering (for GaAs), and mobility saturation in a high electric field was taken into account. Several generation-recombination mechanisms were included: impact ionization, Shockley-Read-Hall recombination (SRH) with doping-dependent lifetimes, trap-assisted tunnelling, band-to-band tunnelling, Auger recombination, and radiative recombination (for GaAs). We show that the so-called critical current density for plasma formation in the submicron diodes increases with the active layer thickness decrease and almost does not depend on the doping density in the active layer. The critical current density for silicon diodes is about two times lower than for the GaAs diodes. The intensive minority carrier storage in the $\mathrm{N}^{+}$and $\mathrm{P}^{+}$regions has a high influence on the voltage oscillation amplitude and frequency after the first plasma formation and extraction period. Oscillation damping takes place in the $\mathrm{N}^{+} \mathrm{NP}^{+}$GaAs diode with the active layer thickness of less than $0.3 \mu \mathrm{m}$.
\end{abstract}

Keywords: simulation, avalanche diodes, mobility, minority carrier storage

PACS: $85.30 . \mathrm{Mn}$

\section{Introduction}

TRAPATT diodes were invented in [1] as high-power microwave devices working with high efficiency. The best achieved result on efficiency (75 percent) was reported in [2]. Peak power output of $1.2 \mathrm{~kW}$ at $1.9 \mathrm{GHz}$ with $24 \%$ efficiency from five series-connected diodes has been obtained in [3]. Very important results on powerful TRAPATT diodes were reported in [4]. The physical mechanism of the new avalanche diode operation mode was described in [5] by computer simulation. The analytical model of the TRAPATT diode was proposed in [6. the transit time mode, the main role in achieving high efficiency is played by the space charge of the carriers generated during the short but extremely intensive avalanche process in the whole active region of the diode. If the total current density is sufficiently high, the space charge density of free carriers exceeds the density of the ionized impurity several times and defines the electric field shape in the active region. The generated electrons and holes move in opposite directions. This causes the electric field to drop to a very low value during several picoseconds. As a result, we have electron-hole-ionized impurity plasma in the active region of the diode. The plasma extraction period (up to several hundred picoseconds) in a low electric field follows the plasma formation process. Due to a relatively long plasma extraction period, the frequency of the TRAPATT generator is several times lower than in the transit time mode. The maximum frequency of the TRAPATT generator obtained experimentally is in the X-band [8, 9]. TRAPATT diodes are suitable for phased-array radar systems [10]. In [11-13] it was shown that TRAPATT diodes are useful not only for generating sinusoidal oscillation, but for generating triangular pulses with sub-nanosecond duration as well. Optical synchronization, amplification, frequency, and amplitude modulation were demonstrated experimentally [14-16].

Due to the above-mentioned advantages TRAPATT diodes have been useful for microwave power generation up to now. But these diodes have several disadvantages: start-up jitter when using TRAPATT diodes for microwave pulse generation in modern radar systems, relatively high current density, and relatively low frequency (less than $10 \mathrm{GHz}$ ). The start-up jitter may be substantially reduced by proper design of the external circuit of the TRAPATT generator and by using $\mathrm{P}^{+} \mathrm{PN}^{+}$or P-type Schottky diodes [17]. 
The generation frequency increase may be achieved by using silicon or GaAs TRAPATT diodes with a submicron active layer. We carefully inspected the literature on TRAPATT diodes and have not found any papers with experimental or theoretical investigation of silicon submicron TRAPATT diodes. We also have not found any papers on GaAs TRAPATT diodes.

The main processes in the TRAPATT diode are: electron-hole plasma formation due to very intensive impact ionization in a high electric field and plasma extraction in a low electric field. The plasma formation process and the resulting plasma density depend on the $\mathrm{N}^{+} \mathrm{N}$ interface steepness [18, 19], on the electron diffusion coefficient in the high electric field [19], and on the dynamic minority carrier storage [20, 21]. Because of the dynamic minority carrier storage, the initial conditions for the first and the second oscillation period are not the same. We have aperiodic oscillation which may be the reason of oscillation jitter in the real external circuit of the TRAPATT generator. In [20] the dynamic minority carrier storage was obtained for the first time in the $\mathrm{N}^{+} \mathrm{NP}^{+}$diode. In [21] a comparison between $\mathrm{N}^{+} \mathrm{NP}^{+}$and $\mathrm{P}^{+} \mathrm{PN}^{+}$diodes was made, but with the assumption that the carrier diffusion coefficient is independent of the electric field and the doping density. Thus, we can consider these results as qualitative results, because the carrier diffusion coefficient dependence on the electric field strongly affects the plasma formation process in the TRAPATT diode [19]. The detailed simulation of various silicon TRAPATT diodes with a $2-3 \mu \mathrm{m}$ active layer was made in [17]. The most periodic oscillation was obtained in the P-type Schottky diodes without a $\mathrm{P}^{+}$layer.

In all above-mentioned calculations, carrier-carrier scattering, Shockley-Read-Hall recombination with doping dependent lifetimes, trap-assisted tunnelling, Auger recombination, band-to-band tunnelling, and radiative recombination were not taken into account.

The main purpose of our work is computer simulation of submicron TRAPATT diodes for the generation of oscillation with the frequency above $10 \mathrm{GHz}$ and a comparison of silicon and GaAs TRAPATT diodes.

\section{TRAPATT diode model}

The doping distribution in the modelled TRAPATT diodes is shown in Fig. 1. Donor $N_{d}(x)$ and acceptor $N_{\mathrm{a}}(x)$ distribution is approximated by a well-known function $\operatorname{erfc}(x)$ [19], where $x$ is distance, donor and acceptor density at the contacts $N_{\mathrm{d} 0}=5 \cdot 10^{18} \mathrm{~cm}^{-3}$ and $N_{\mathrm{a} 0}=10^{19} \mathrm{~cm}^{-3}$, donor density in the active lay- er $N_{\mathrm{d} 1}=2.4 \cdot 10^{15} \mathrm{~cm}^{-3}$ and $10^{16} \mathrm{~cm}^{-3}$, and total length of the $\mathrm{N}^{+} \mathrm{NP}^{+}$diodes $w=0.6$ and $0.7 \mu \mathrm{m}$. The $\mathrm{N}^{+} \mathrm{N}$ junction steepness described by the parameter $l_{\mathrm{d}}=0.01 \mu \mathrm{m}$. The $\mathrm{NP}^{+}$junction steepness described by the parameter $l_{\mathrm{a}}=0.01$ and $0.05 \mu \mathrm{m}$. We also investigated a simplified Schottky diode without a $\mathrm{N}^{+}$ region. This diode consists of only an active $\mathrm{N}$ region and a Schottky barrier on the right side of it. The total length of the simplified diode $w=0.2 \mu \mathrm{m}$. Because of the diode simplicity it is not shown in Fig. 1 .

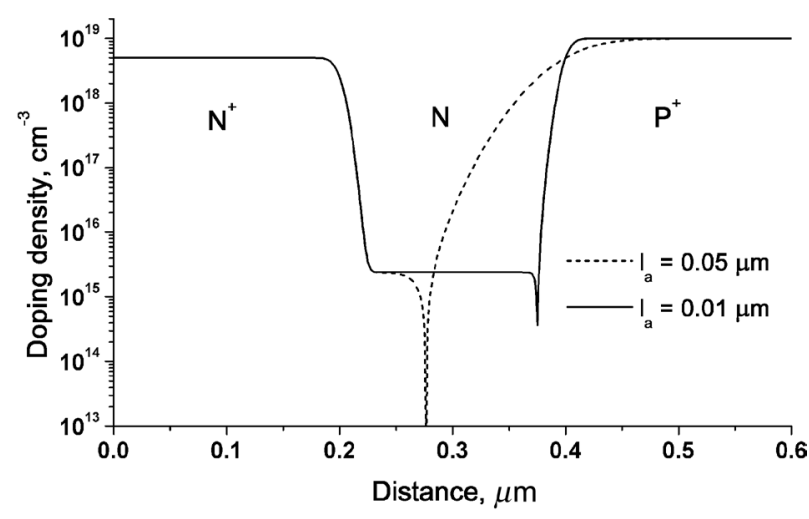

Fig. 1. Doping distribution of simulated $\mathrm{N}^{+} \mathrm{NP}^{+}$ TRAPATT diodes.

For computer simulation of the TRAPATT diodes we used Boltzmann statistics at lattice temperature $T=300 \mathrm{~K}$ and a one-dimension quasi-hydrodynamic model based on Poisson's equation for electrostatic potential, continuity equations for electrons and holes, and energy balance equations for electrons and holes according to Synopsys TCAD Sentaurus:

$$
\begin{aligned}
& \nabla \cdot \varepsilon \nabla \phi=-q\left(p-n+N_{\mathrm{d}}(x)-N_{\mathrm{a}}(x)\right), \\
& q \frac{\partial n}{\partial t}-\nabla \cdot J_{\mathrm{n}}=q G_{\mathrm{ii}}-q R_{\mathrm{net}}, \\
& q \frac{\partial p}{\partial t}+\nabla \cdot J_{\mathrm{p}}=q G_{\mathrm{ii}}-q R_{\mathrm{net}}, \\
& \frac{\partial W_{\mathrm{n}}}{\partial t}+\nabla \cdot S_{\mathrm{n}}=J_{\mathrm{n}} \cdot \nabla E_{\mathrm{C}}-\xi_{\mathrm{n}} \frac{W_{\mathrm{n}}-W_{\mathrm{n} 0}}{\tau_{\mathrm{en}}}, \\
& \frac{\partial W_{\mathrm{p}}}{\partial t}+\nabla \cdot S_{\mathrm{p}}=J_{\mathrm{p}} \cdot \nabla E_{\mathrm{V}}-\xi_{\mathrm{p}} \frac{W_{\mathrm{p}}-W_{\mathrm{p} 0}}{\tau_{\mathrm{ep}}}
\end{aligned}
$$

where $t$ is time, $n$ is electron density, $p$ is hole density, $\phi$ is electrostatic potential, $J_{n}, J_{p}$ are the electron and hole current densities, $G_{\mathrm{ii}}$ is the charge generation 
term due to impact ionization, $R_{\text {net }}$ is the net recombination rate, $q$ is the electronic charge, $\varepsilon$ is electrical permittivity, $W_{\mathrm{n}}, W_{\mathrm{p}}$ are the electron and hole energy densities, $S_{\mathrm{n}}, S_{\mathrm{p}}$ are the electron and hole energy fluxes, $E_{\mathrm{C}}, E_{\mathrm{V}}$ are conduction and valence band edges, $W_{\mathrm{n} 0}, W_{\mathrm{p} 0}$ are the energy densities at $T_{\mathrm{n}}=T_{\mathrm{p}}=T, T_{\mathrm{n}}$, $T_{\mathrm{p}}$ are the electron and hole temperatures, the energy relaxation times for electrons and holes $\tau_{\text {en }}=0.3 \mathrm{ps}$, $\tau_{\text {ep }}=0.25 \mathrm{ps}$ for silicon and $\tau_{\mathrm{en}}=1 \mathrm{ps}, \tau_{\mathrm{ep}}=0.4 \mathrm{ps}$ for GaAs. The parameters $\xi_{\mathrm{n}}, \xi_{\mathrm{p}}$ improve numeric stability. They speed up relaxation for small densities and they approach 1 for large densities:

$$
\xi_{\mathrm{n}}=1+\frac{n_{\min }}{n}\left(\frac{n_{0}}{n_{\min }}\right)^{\max \left[0,\left(T-T_{\mathrm{n}}\right) / 100 K\right]}
$$

and likewise for $\xi_{\mathrm{p}}$. Here, $n_{\min }$ and $n_{0}$ are adjustable small density parameters.

$$
\begin{aligned}
& J_{\mathrm{n}}=\mu_{\mathrm{n}}\left(n \nabla E_{\mathrm{C}}+k T_{\mathrm{n}} \nabla n\right), \\
& J_{\mathrm{p}}=\mu_{\mathrm{p}}\left(p \nabla E_{\mathrm{V}}+k T_{\mathrm{p}} \nabla p\right),
\end{aligned}
$$

where $\mu_{\mathrm{n}}, \mu_{\mathrm{p}}$ are the electron and hole mobility, $k$ is Boltzmann constant.

The net recombination rate

$$
R_{\text {net }}=R_{\text {net }}^{\mathrm{SRH}}+R_{\text {net }}^{\mathrm{A}}+R_{\text {net }}^{\mathrm{BB}}+R_{\text {net' }}^{\mathrm{R}}
$$

where $R_{\text {net }}^{\text {SRH }}$ is Shockley-Read-Hall recombination rate with doping dependent [22] and field dependent (Schenk trap-assisted tunnelling model [23]) lifetimes for electrons and holes, $R_{\text {net }}^{\mathrm{A}}$ is the band-to-band Auger recombination rate with temperature dependent Auger coefficients for silicon [24-26], $R_{\text {net }}^{\mathrm{BB}}$ is the band-to-band tunnelling rate [27], $R_{\text {net }}^{\mathrm{R}}$ is the radiative recombination rate (for GaAs). The doping-dependent bandgap narrowing $E_{\text {bgn }}$ was calculated using the Slotboom model [28-31].

The energy densities are given by:

$$
\begin{aligned}
& W_{\mathrm{n}}=n\left(\frac{3 k T_{\mathrm{n}}}{2}\right), \\
& W_{\mathrm{p}}=p\left(\frac{3 k T_{\mathrm{p}}}{2}\right) .
\end{aligned}
$$

The energy fluxes are:

$$
S_{\mathrm{n}}=-\frac{5 r_{\mathrm{n}} \lambda_{\mathrm{n}}}{2}\left(\frac{k T_{\mathrm{n}}}{q} J_{\mathrm{n}}+f_{\mathrm{n}}^{\mathrm{hf}} \hat{\kappa}_{\mathrm{n}} \nabla T_{\mathrm{n}}\right),
$$

$$
\begin{aligned}
& S_{\mathrm{p}}=-\frac{5 r_{\mathrm{p}} \lambda_{\mathrm{p}}}{2}\left(\frac{-k T_{\mathrm{p}}}{q} J_{\mathrm{p}}+f_{\mathrm{p}}^{\text {hf }} \hat{\kappa}_{\mathrm{p}} \nabla T_{\mathrm{p}}\right), \\
& \hat{\kappa}_{\mathrm{n}}=\frac{k^{2}}{q} n \mu_{\mathrm{n}} T_{\mathrm{n}}, \\
& \hat{\kappa}_{\mathrm{p}}=\frac{k^{2}}{q} p \mu_{\mathrm{p}} T_{\mathrm{p}},
\end{aligned}
$$

where $\lambda_{\mathrm{n}}=\lambda_{\mathrm{p}}=1, r_{\mathrm{n}}=r_{\mathrm{p}}=0.6, f_{\mathrm{n}}^{\mathrm{h} f}=f_{\mathrm{p}}^{\mathrm{hf}}=1$.

The generation rate due to impact ionization can be expressed as

$$
G_{\mathrm{ii}}=\alpha_{\mathrm{n}} n v_{\mathrm{n}}=\alpha_{\mathrm{p}} p v_{\mathrm{p}}
$$

where $\alpha_{\mathrm{n}}, \alpha_{\mathrm{p}}$ are the ionization coefficients for electrons and holes, $v_{\mathrm{n}}, v_{\mathrm{p}}$ are the electron and hole drift velocities. For calculation of the ionization coefficients we used the van Overstraeten and de Man model [32] based on the Chynoweth law:

$$
\alpha\left(F^{\mathrm{eff}}\right)=a \exp \left(-\frac{b}{F^{\mathrm{eff}}}\right) .
$$

The effective field $F_{\mathrm{n}}^{\text {eff }}$ for electrons was calculated using the expression

$$
\begin{aligned}
& n v_{\text {sat, } \mathrm{n}} F_{\mathrm{n}}^{\text {eff }}=\frac{n 3 k\left(T_{\mathrm{n}}-T\right)}{2 q \lambda_{\mathrm{n}} \tau_{\text {en }}}+ \\
& +\frac{\gamma_{\mathrm{n}}}{q}\left(E_{\mathrm{g}}+\delta_{\mathrm{n}} k T_{\mathrm{n}}\right) \alpha_{\mathrm{n}} n v_{\mathrm{sat}, \mathrm{n}},
\end{aligned}
$$

where $v_{\text {sat, } n}$ is the electron saturation velocity. A similar equation is used to determine $F_{\mathrm{p}}^{\text {eff. }}$. The parameters $\gamma_{\mathrm{n}}=\gamma_{\mathrm{p}}=1$ for silicon and equal to zero for GaAs, $\delta_{\mathrm{n}}=\delta_{\mathrm{p}}=3 / 2$.

The carrier mobility dependence on phonon scattering, impurity scattering, carrier-carrier scattering, intervalley scattering (for GaAs), and mobility saturation in a high electric field was taken into account. The electron and hole low field mobility in the undoped semiconductor due to phonon scattering $\mu_{\mathrm{n}}=1417 \mathrm{~cm}^{2} / \mathrm{Vs}, \mu_{\mathrm{p}}=470.5 \mathrm{~cm}^{2} / \mathrm{Vs}$ for silicon and $\mu_{\mathrm{n}}=8500 \mathrm{~cm}^{2} / \mathrm{Vs}, \mu_{\mathrm{p}}=400 \mathrm{~cm}^{2} / \mathrm{Vs}$ for GaAs. The doping-dependent mobility proposed by Masetti et al. [33] was used for silicon. The doping-dependent mobility for GaAs was calculated using the Arora model [34]. The carrier-carrier scattering model is based on Choo [35] and Fletcher [36]. This model was used for silicon.

The mobility saturation in a high electric field for electrons and holes in silicon and for holes in GaAs describes the Canali model [37]. 
For GaAs a negative differential mobility can be observed for high driving fields. TCAD Sentaurus includes a transferred electron model for the description of this effect, as given by [38].

The contacts on semiconductors are ohmic. The charge neutrality and equilibrium are assumed at Ohmic contacts:

$$
\begin{aligned}
& n_{0}-p_{0}=N_{\mathrm{d}}-N_{\mathrm{a}}, \\
& n_{0} p_{0}=n_{\mathrm{i}, \mathrm{eff}}^{2},
\end{aligned}
$$

where $n_{0}, p_{0}$ are the electron and hole equilibrium concentrations, $n_{\mathrm{i} \text { eff }}$ is the effective intrinsic density (including doping-dependent bandgap narrowing).

At the Schottky contact the following boundary conditions hold:

$$
\begin{aligned}
& \phi=\phi_{\mathrm{F}}-\Phi_{B}+\frac{k T}{q} \ln \left(\frac{N_{C}}{n_{\mathrm{i}, \text { eff }}}\right), \\
& J_{\mathrm{n}}=q v_{\mathrm{n}}\left(n-n_{0}^{\mathrm{B}}\right), \\
& J_{\mathrm{p}}=q v_{\mathrm{p}}\left(p-p_{0}^{\mathrm{B}}\right), \\
& n_{0}^{\mathrm{B}}=N_{\mathrm{C}} \exp \left(\frac{-q \Phi_{\mathrm{B}}}{k T}\right), \\
& p_{0}^{\mathrm{B}}=N_{\mathrm{V}} \exp \left(\frac{-E_{\mathrm{g}, \text { eff }}+q \Phi_{\mathrm{B}}}{k T}\right),
\end{aligned}
$$

where $\phi_{\mathrm{F}}$ is the Fermi potential at the contact which equals the applied voltage, $N_{\mathrm{C}}, N_{\mathrm{v}}$ are the density of states in conduction and valence band, $E_{\mathrm{g}, \text { eff }}=E_{\mathrm{g}}-E_{\mathrm{bgn}}, E_{\mathrm{g}}$ is the bandgap, $\Phi_{\mathrm{B}}$ is the barrier height (the difference between the contact workfunction and the electron affinity of the semiconductor), $v_{\mathrm{n}}=2.573 \cdot 10^{6} \mathrm{~cm} / \mathrm{s}, v_{\mathrm{p}}=1.93 \cdot 10^{6} \mathrm{~cm} / \mathrm{s}$ are the thermionic emission velocities. The barrier-lowering model for Schottky contact was taken into account.

For the carrier temperatures $T_{\mathrm{n}}$ and $T_{\mathrm{p}}$, at the thermal contacts, fast relaxation to the lattice temperature (boundary condition $T_{\mathrm{n}}=T_{\mathrm{p}}=T$ ) is assumed.

Almost all calculations were made assuming a constant total current density. An external circuit containing capacitances or other elements was not used. The boundary conditions for the electric field $F$ (the derivative of the electrostatic potential) were calculated by solving the equation for the total current density:

$$
J(t)=\varepsilon \frac{\partial F}{\partial t}+J_{\mathrm{n}}+J_{\mathrm{p}} .
$$

The set of the above-mentioned nonlinear equations derived in difference form was solved using the Newton method.

\section{The computer simulation results}

The typical voltage oscillation on the silicon $\mathrm{N}^{+} \mathrm{NP}^{+}$ TRAPATT diode (total current density $J=74.7 \mathrm{kA} /$ $\mathrm{cm}^{2}$ ) is shown in Fig. 2. The carrier density in the depletion region at the beginning of the first oscillation period is very low, about $10^{3}-10^{4} \mathrm{~cm}^{-3}$. Thus, almost the whole current is a displacement current and we have the electric field increasing at a constant rate. As we can see in Fig. 2, the diode voltage increases linearly until very intensive impact ionization begins. The carrier density increases rapidly. Near the voltage maximum point the carrier density becomes much larger than the donor density in the active layer, and according to Poisson's equation the carrier density defines the electric field shape. In the active layer the electric field decreases with time. The diode voltage decreases as well. In the time interval of about several picoseconds the diode voltage decreases to a very low value. We have a very high carrier density (above $10^{16} \mathrm{~cm}^{-3}$ ) in a low electric field $(600-700 \mathrm{~V} /$ $\mathrm{cm})$. Almost in the whole active region $n-p=N_{\mathrm{d} 1}$, which indicates electron-hole-ionized donor plasma. The next process is the plasma extraction in the low field. After this process (15-20 ps) the diode voltage increases again and the next oscillation period begins. The oscillation period depends on the plasma extraction time. It depends on the carrier density in plasma and the applied total current density. Larger current density leads to a more rapid increase of diode voltage, a higher voltage maximum, and a more intensive impact ionization process. As a result we have a denser electron-hole plasma and a prolonged plasma

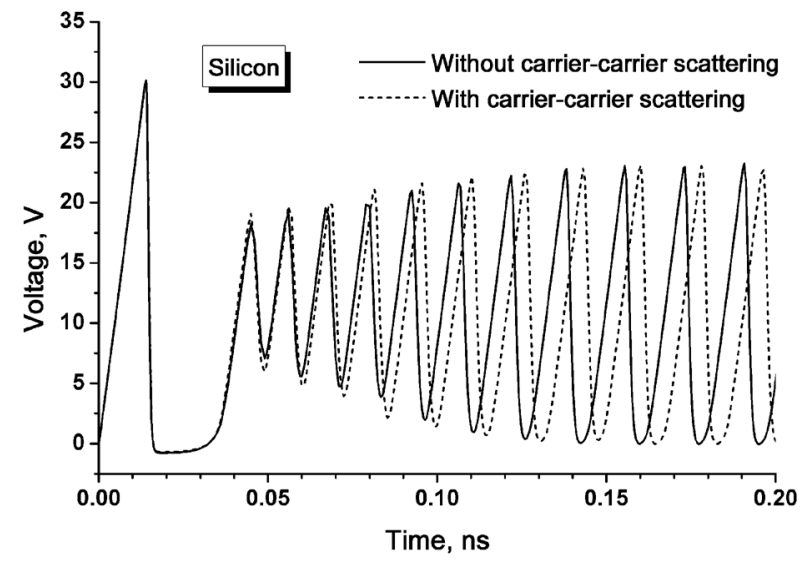

Fig. 2. Voltage oscillation on the silicon $\mathrm{N}^{+} \mathrm{NP}^{+}$ TRAPATT diode with $w_{\mathrm{a}}=0.3 \mu \mathrm{m}$ at total current density $J=74.7 \mathrm{kA} / \mathrm{cm}^{2}$. 
extraction process. Thus, the first oscillation period increases with the total current density increase. All next oscillation periods differ from the first one sufficiently (Fig. 2) due to a very high total current density needed for diodes with a submicron active layer. The difference between the first and second voltage oscillation periods is much greater than in the diodes with the active layer of several microns [17]. The high current density leads to a high voltage increasing rate and a very short increasing time after plasma extraction. The minority carriers accumulated in $\mathrm{N}^{+}$and $\mathrm{P}^{+}$ regions need more time for extraction. They support a residual carrier density in the active region that is several orders higher than at the beginning of the first oscillation period. As a result, we have a very early impact ionization process, a low voltage maximum, a low carrier density in the plasma, and a very short second oscillation period. The oscillation amplitude increases with time. This transient process continues for about $100 \mathrm{ps}$.

In Fig. 2 we can see the effect of carrier-carrier scattering on voltage oscillation of a silicon TRAPATT diode with the active layer thickness of $0.3 \mu \mathrm{m}$. The carrier-carrier scattering does not change the first oscillation period. The oscillation amplitude differs slightly during the transient process. The frequency and amplitude of the steady state oscillation does not depend on carrier-carrier scattering.

The total current density must exceed the critical current density $J_{\text {cr }}$ for plasma formation in the diode. The simple analytical theory of the TRAPATT diode [6, \#] shows that

$$
J_{\text {cr }}=q N_{\mathrm{d} 1} v_{\text {sat }},
$$

where $N_{\mathrm{d} 1}$ is the donor density in the active layer, $v_{\text {sat }}$ is the electron saturation velocity in a high electric field. Equation (3.27) is based on the assumption that the impact ionization wave propagates from the $\mathrm{NP}^{+}$interface to the $\mathrm{N}^{+}$region during the plasma formation period. When $J>J_{c r}$, the wave propagation velocity $v_{\mathrm{w}}>v_{\text {sat }}$ and the carriers accumulate in the active layer filling it with electron-hole-ionized donor plasma. This theory works very well for relatively long diodes. In the diodes with the active layer thickness $w_{\mathrm{a}}$ of about $3 \mu \mathrm{m}$ we have the electric field collapse in the centre of the diode propagating to the left and to the right at the same time [17]. The critical current density in these diodes is about two times less than we can obtain from Eq. (3.27). $J_{\mathrm{cr}}=q N_{\mathrm{d} 1} v_{\text {sat }}$ for silicon diodes with the active layer of about $1 \mu \mathrm{m}$ and for GaAs diodes with the active layer of about $1.2 \mu \mathrm{m}$ (Fig. 3). For the active layer thickness of less than $0.5 \mu \mathrm{m}$, the critical current density increases dramatically (Fig. 3 ). $J_{\mathrm{cr}}=45 \mathrm{kA} / \mathrm{cm}^{2}$

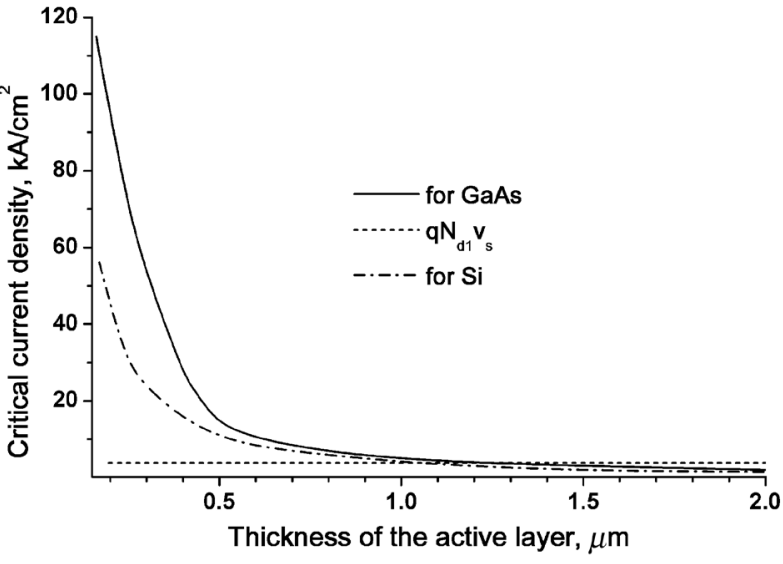

Fig. 3. Critical current density for silicon and GaAs $\mathrm{N}^{+} \mathrm{NP}^{+}$TRAPATT diodes.

for the silicon diode, and $J_{\mathrm{cr}}=95 \mathrm{kA} / \mathrm{cm}^{2}$ for the GaAs diode with $w_{\mathrm{a}}=0.2 \mu \mathrm{m}$. This effect can be explained as follows. The dynamic avalanche breakdown voltage $U_{\text {dyn }}$ necessary for plasma formation is several times greater than the static breakdown voltage $U_{\text {st }} \cdot U_{\text {dyn }}$ may be achieved only when the voltage increasing rate is sufficiently high. This rate is inversely proportional to the depletion layer capacitance and directly proportional to the total current density which is almost displacement current density before intensive impact ionization begins. The depletion layer capacity of the diodes with $w_{\mathrm{a}}>1 \mu \mathrm{m}$ is relatively low and the critical current density depends mainly on $N_{\mathrm{d} 1}$ according to Eq. (3.27). For the diodes with $w_{\mathrm{a}}<1 \mu \mathrm{m}$ the depletion layer capacitance is sufficient and $J_{\text {cr }}$ is inversely proportional to the active layer thickness and does not depend on the doping density in the active layer. The diode voltage oscillation remains almost the same when changing the doping density from $2.4 \cdot 10^{15} \mathrm{~cm}^{-3}$ to $10^{16} \mathrm{~cm}^{-3}$ (Fig. A). The voltage oscillation in Figs. 2 and 4 shows that

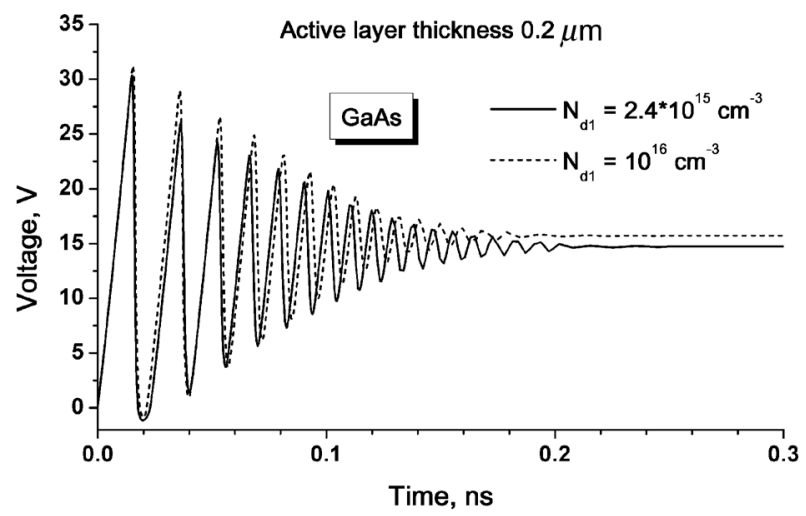

Fig. 4. Voltage oscillation on the $\mathrm{N}^{+} \mathrm{NP}^{+} \mathrm{GaAs}$ TRAPATT diode with the various doping density in the active layer. Total current density $J=112 \mathrm{kA} / \mathrm{cm}^{2}$. 
oscillation frequency of up to $50 \mathrm{GHz}$ may be achieved using silicon and GaAs TRAPATT diodes. The main disadvantage of these diodes is an extremely high current density which restricts the practical application of TRAPATT diodes with $w_{\mathrm{a}}<0.2 \mu \mathrm{m}$. The critical current density for silicon diodes is about two times lower than for the GaAs diodes. This fact may be explained as follows. The bandgap of GaAs is about 1.5 times wider than of silicon. So, the dynamic breakdown voltage is higher. The electrical permittivity of GaAs is higher than that of silicon and as a consequence the depletion layer capacitance is higher. As a result, we need higher current density for reaching $U_{\mathrm{dyn}}$ at the same time as in silicon diodes. Thus, silicon diodes are more appropriate for practical application than GaAs ones.

In Fig. 5 we can see the trap-assisted tunnelling effect on voltage oscillation of a GaAs TRAPATT diode. The oscillation amplitude is lower and the frequency is higher when the trap-assisted tunnelling is taken into account. The tunnelling begins at a relatively low electric field of about $3 \cdot 10^{5} \mathrm{~V} / \mathrm{cm}$. The positive values of

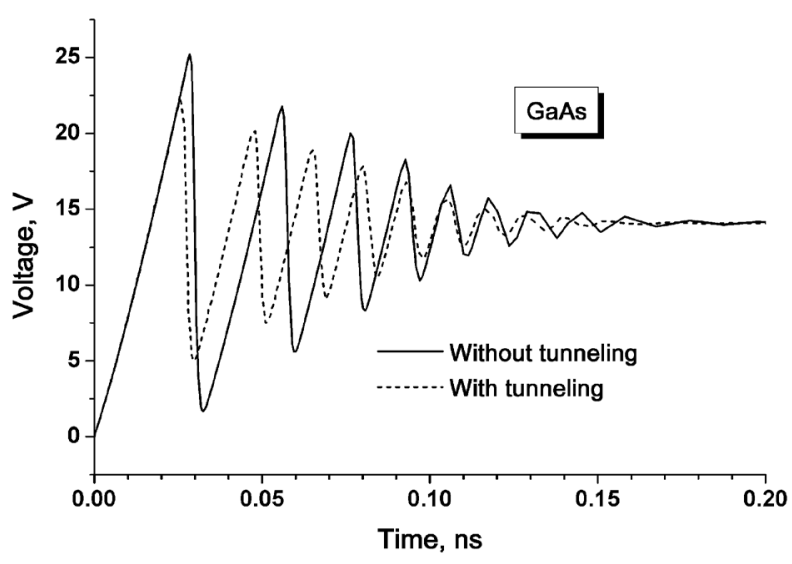

Fig. 5. Voltage oscillation on the $\mathrm{N}^{+} \mathrm{NP}^{+} \mathrm{GaAs}$ TRAPATT diode with $w_{\mathrm{a}}=0.2 \mu \mathrm{m}$ and $l_{\mathrm{a}}=0.05 \mu \mathrm{m}$ with and without trap-assisted tunnelling. Total current density $J=$ $56 \mathrm{kA} / \mathrm{cm}^{2}$.

$R_{\text {net }}^{\mathrm{SRH}}$ in Fig. 6 mean the carrier recombination rate and the negative values mean the carrier generation rate. At the beginning of the first oscillation period $(t=14 \mathrm{ps}$, Fig. 6) $R_{\text {net }}^{\mathrm{SRH}}$ with tunnelling is several orders greater than $R_{\text {net }}^{\text {nRH }}$ without tunnelling and the avalanche generation rate. As a result, the carrier density in the active layer at the beginning of the oscillation period is about three orders higher (Fig. ఫ). Due to this carrier density, avalanche generation begins earlier and the voltage maximum becomes lower resulting in a lower carrier density in plasma and a more rapid plasma extraction. The trap-assisted tunnelling effect on voltage

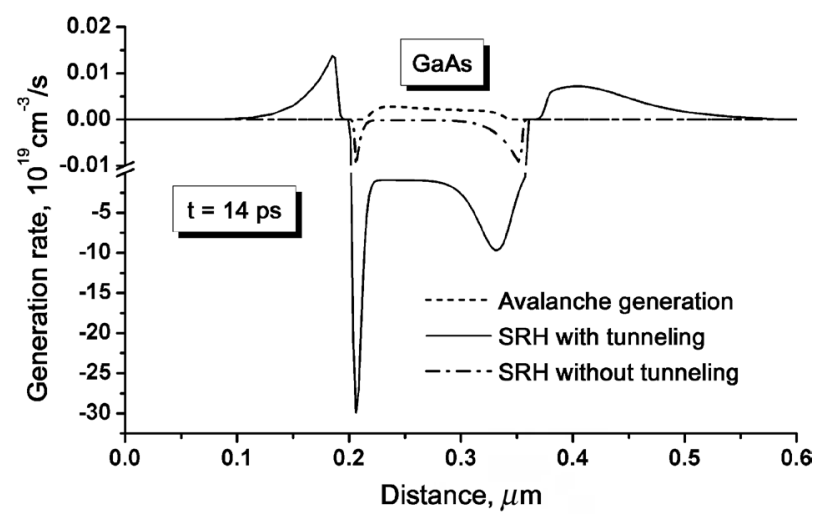

Fig. 6. Avalanche generation and SRH generation-recombination rate in the $\mathrm{N}^{+} \mathrm{NP}^{+}$GaAs TRAPATT diode with $w_{\mathrm{a}}=0.2 \mu \mathrm{m}$ and $l_{\mathrm{a}}=0.05 \mu \mathrm{m}$ with and without trapassisted tunnelling. Total current density $J=56 \mathrm{kA} / \mathrm{cm}^{2}$.

oscillation of silicon diodes is inferior to that on GaAs diodes, because the bandgap in silicon is narrower than in GaAs. The impact ionization in silicon begins at a lower electric field and the $R_{\text {net }}^{\text {SRH }}$ comprises a lower part in the overall charge generation rate.

The band-to-band tunnelling takes place at the electric field higher than $8 \cdot 10^{5} \mathrm{~V} / \mathrm{cm}$. At such high electric field the avalanche generation rate is about six to seven orders greater than the generation rate due to the band-to-band tunnelling. Thus, the effect is negligible and we cannot see any difference in voltage oscillation with and without band-to-band tunnelling.

The Auger and radiative recombination rate is negligible in comparison with the $R_{\text {net }}^{\text {SRH }}$. Thus, the Auger and radiative recombination may be neglected.

The main difference between $\mathrm{N}^{+} \mathrm{NP}^{+}$silicon and GaAs TRAPATT diodes is the voltage oscillation damping on GaAs diodes with the active layer thickness of less than $0.3 \mu \mathrm{m}$ (Fig. 8). This effect may be

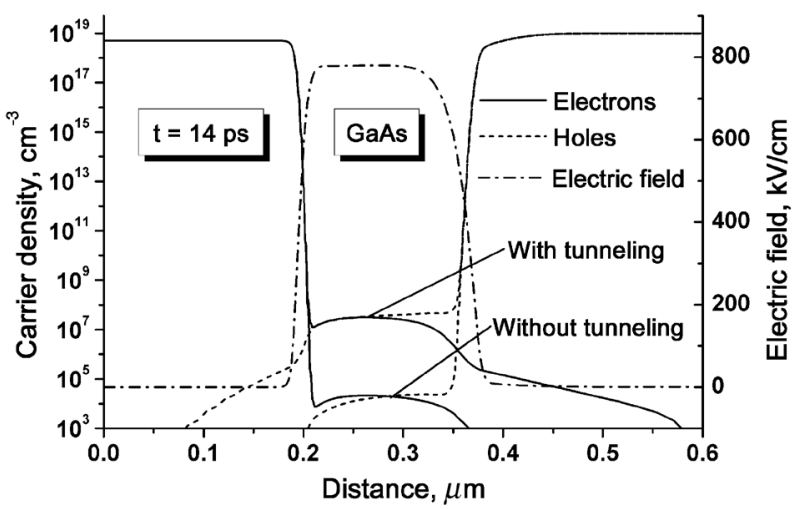

Fig. 7. Carrier and electric field distribution in the $\mathrm{N}^{+} \mathrm{NP}^{+}$GaAs TRAPATT diode with $w_{\mathrm{a}}=0.2 \mu \mathrm{m}$ and $l_{\mathrm{a}}=0.05 \mu \mathrm{m}$ with and without trap-assisted tunnelling. Total current density $J=56 \mathrm{kA} / \mathrm{cm}^{2}$. 


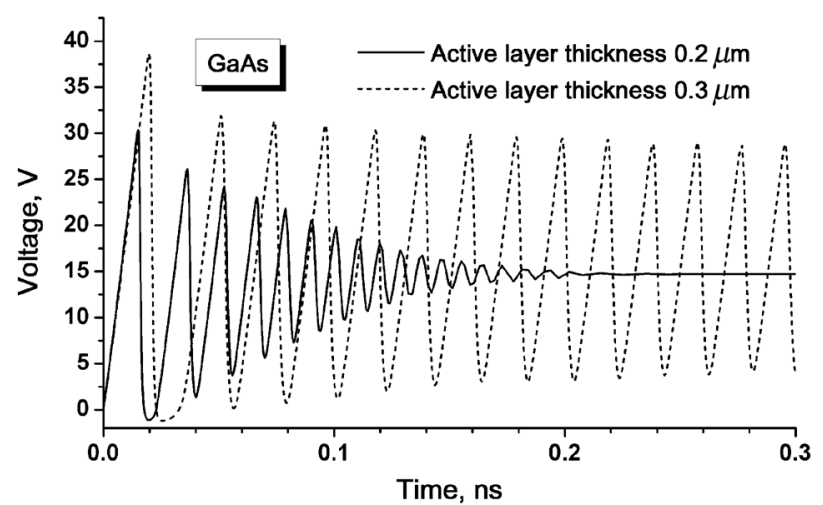

Fig. 8. Voltage oscillation on the $\mathrm{N}^{+} \mathrm{NP}^{+} \mathrm{GaAs}$ TRAPATT diode with $w_{\mathrm{a}}=0.2 \mu \mathrm{m}\left(J=112 \mathrm{kA} / \mathrm{cm}^{2}\right)$ and $w_{\mathrm{a}}=0.3 \mu \mathrm{m}\left(J=74.7 \mathrm{kA} / \mathrm{cm}^{2}\right)$.

explained as follows. The initial carrier density in the active layer at the beginning of the first and second voltage oscillation periods is different mainly due to the minority carrier accumulation in the $\mathrm{N}^{+}$and $\mathrm{P}^{+}$ layers. The thickness of these layers is the same in all simulated diodes. Thus, the accumulated charge is almost the same as well (depends on the total current density). After the plasma formation period the electrons and holes move from the $\mathrm{P}^{+}$and $\mathrm{N}^{+}$regions to the active region. So, the initial carrier density at the beginning of the second oscillation period is by several orders higher than at the beginning of the first period. The smaller the active region, the higher the density of the initial carriers. In the diode with the active layer of $0.2 \mu \mathrm{m}$ the initial carrier density increases from one period to the next (Fig. 9) which causes the voltage oscillation amplitude to decrease with time (Fig. 8). In silicon diodes with the same active layer

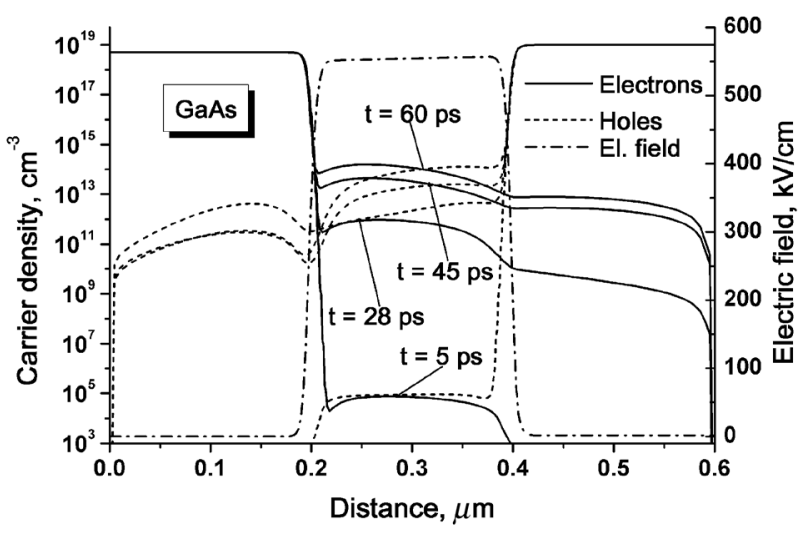

Fig. 9. Carrier density and electric field distribution in the $\mathrm{N}^{+} \mathrm{NP}^{+} \mathrm{GaAs}$ TRAPATT diode with $w_{\mathrm{a}}=0.2 \mu \mathrm{m}$ at the beginning of the first four oscillation periods. Total current density $J=112 \mathrm{kA} / \mathrm{cm}^{2}$. thickness the initial carrier density decreases from one period to the next and we have the voltage oscillation amplitude increasing with time. The carrier extraction from the active layer in silicon diodes is more rapid than in GaAs diodes due to higher electron velocity in the electric field of about $10^{5} \mathrm{~V} / \mathrm{cm}$.

The voltage oscillation damping effect is sufficiently lower in the diodes without $\mathrm{N}^{+}$and $\mathrm{P}^{+}$regions. We calculated a GaAs N-type Schottky diode without the $\mathrm{N}^{+}$ region and with the active layer thickness of $0.2 \mu \mathrm{m}$. Some oscillation damping takes place during the transient period of about 100 ps. After that period we have steady state oscillation with the constant amplitude and the frequency exceeding $50 \mathrm{GHz}$ (Fig. 10). Thus, the N-type GaAs Schottky diode is more appropriate than the $\mathrm{N}^{+} \mathrm{NP}^{+}$diode for the generation of microwave power with the frequency above $50 \mathrm{GHz}$.

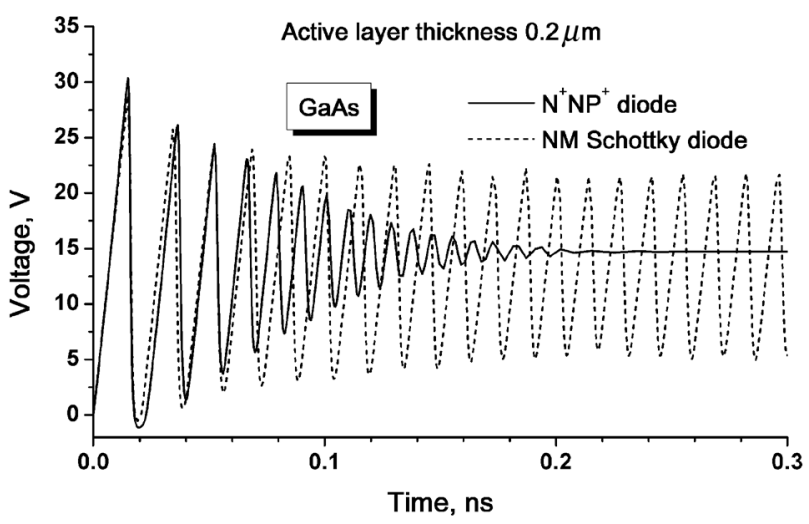

Fig. 10. Voltage oscillation on the $\mathrm{N}^{+} \mathrm{NP}^{+}$and $\mathrm{NM}$ Schottky GaAs TRAPATT diode with $w_{\mathrm{a}}=0.2 \mu \mathrm{m}$. Total current density $J=112 \mathrm{kA} / \mathrm{cm}^{2}$.

All our calculations made at a constant total current density show the maximum oscillation frequency which may be achieved by the TRAPATT generator. Any real TRAPATT generator consists of a TRAPATT diode and an external circuit. In such a circuit total current does not remain constant during the oscillation period. In the Kawamoto circuit [11] the shape of the current pulses is near to the triangular [13, 16, and does not depend on the oscillation frequency [13. 16. The duration of the pause between the current pulses decreases with frequency and is equal to zero at the maximum frequency. The pause between current pulses is very important for the residual carrier extraction from the active layer after the plasma formation period. The oscillation damping in the GaAs TRAPATT diode may be overcome by using a pulsed total current with the appropriate pause between the pulses. In Fig. 11 we can see a quite periodic 


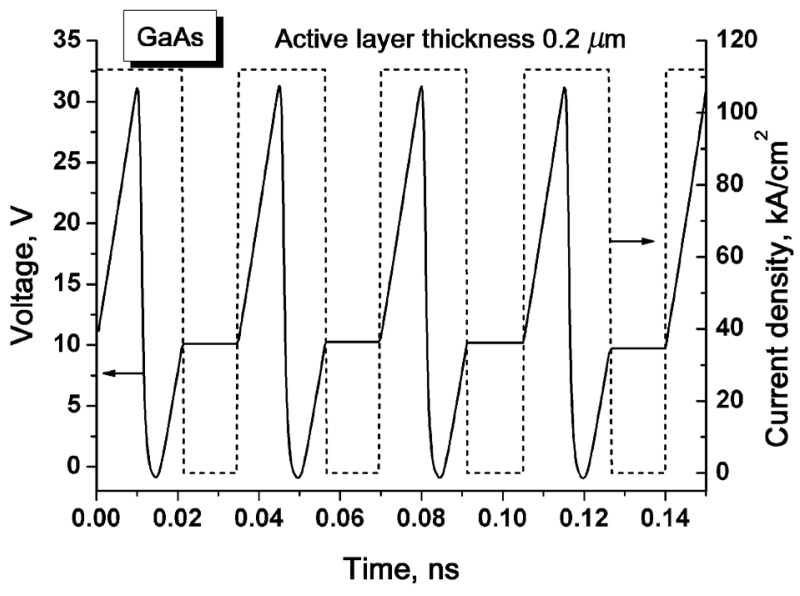

Fig. 11. Current density and voltage oscillation on the $\mathrm{N}^{+} \mathrm{NP}^{+}$GaAs TRAPATT diode with $w_{\mathrm{a}}=0.2 \mu \mathrm{m}$. The amplitude of the total current density pulses $J_{\mathrm{A}}=112 \mathrm{kA} /$ $\mathrm{cm}^{2}$.

oscillation in the $\mathrm{N}^{+} \mathrm{NP}^{+} \mathrm{GaAs}$ TRAPATT diode with the active layer of $0.2 \mu \mathrm{m}$. The period of the current pulses is equal to $35 \mathrm{ps}$. Decreasing the period leads to aperiodic oscillation due to high residual carrier density in the active layer at the beginning of the next oscillation period. The residual carrier density decreases with time during the pause between current pulses (Fig. 12). At $t=35$ ps we have the same carrier density in the active layer as at the beginning of the previous oscillation period. This means that the periodic oscillation at the frequency of $28.6 \mathrm{GHz}$ is the maximum frequency for the $\mathrm{N}^{+} \mathrm{NP}^{+} \mathrm{GaAs}$ TRAPATT diode with the active layer of $0.2 \mu \mathrm{m}$. A much higher frequency (of about $50 \mathrm{GHz}$ ) may be achieved in diodes with the active layer of $0.3 \mu \mathrm{m}$ (Fig. 8). Thus, the production of the $\mathrm{N}^{+} \mathrm{NP}^{+} \mathrm{GaAs}$ TRAPATT diode with the active layer of less than $0.3 \mu \mathrm{m}$ does not make sense.

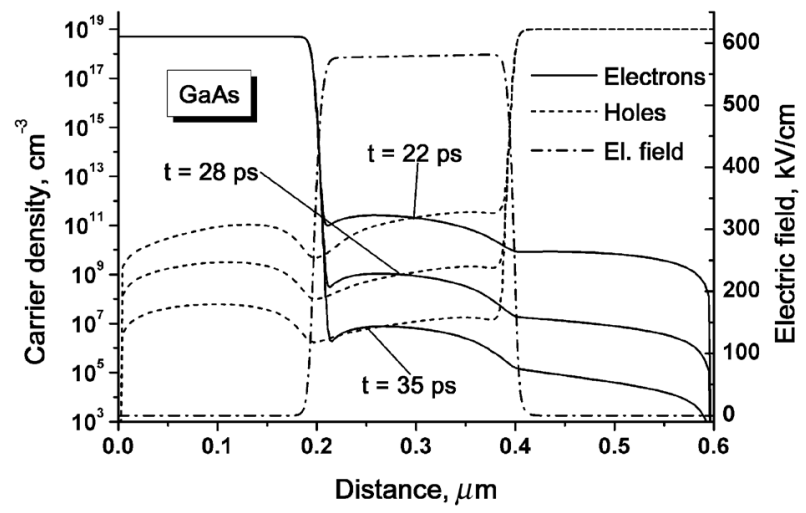

Fig. 12. Carrier density and electric field distribution in the $\mathrm{N}^{+} \mathrm{NP}^{+}$GaAs TRAPATT diode with $w_{\mathrm{a}}=0.2 \mu \mathrm{m}$ during the pause between the first and second current density pulses.

\section{Conclusions}

Plasma formation and extraction processes in submicron silicon and GaAs $\mathrm{N}^{+} \mathrm{NP}^{+}$and GaAs NM Schottky TRAPATT diodes were simulated. The critical current density for plasma formation in such diodes is inversely proportional to the active layer thickness and almost does not depend on the donor density in the active layer. The critical current density in the silicon diodes is about two times less than in the GaAs diodes. The extremely high current density restricts the practical application of TRAPATT diodes with $w_{\mathrm{a}}<0.2 \mu \mathrm{m}$. The carrier-carrier scattering, Auger recombination and band-to-band tunnelling does not have a sufficient effect on the voltage oscillation at the constant current density. However, the trap-assisted tunnelling must be taken into account when modelling TRAPATT diodes with a submicron active layer. The effect is smaller in silicon TRAPATT diodes due to the narrower bandgap in silicon. The main difference between $\mathrm{N}^{+} \mathrm{NP}^{+}$silicon and GaAs TRAPATT diodes is the voltage oscillation damping on GaAs diodes with the active layer thickness of less than $0.3 \mu \mathrm{m}$. The periodic oscillation with the maximum frequency of about $30 \mathrm{GHz}$ in these diodes may be achieved only in the case of pulsed total current with an appropriate duration of the pause between current pulses. Steady state oscillation with the frequency exceeding $50 \mathrm{GHz}$ can be obtained in $\mathrm{N}$-type GaAs Schottky diodes without a $\mathrm{N}^{+}$region and with the active layer of $0.2 \mu \mathrm{m}$.

\section{Acknowledgements}

This study has been supported by the Research Council of Lithuania, grant MIP-060-2013.

\section{References}

[1] H.J. Prager, K.K.N. Chang, and S. Weisbrod, Highpower, high-efficiency silicon avalanche diodes at ultra high frequencies, Proc. IEEE 55(4), 586-587 (1967).

[2] D.F. Kostishack, UHF avalanche diode oscillator providing 400 Watts peak power and 75 percent efficiency, Proc. IEEE 58(8), 1282-1283 (1970).

[3] S.G. Liu, 2000-W-GHz complementary TRAPATT diodes, in: International Solid-State Circuits Conference: Digest of Technical Papers (1973) pp. 124-125.

[4] S.K. Lyubutin, S.N. Rukin, B.G. Slovikovsky, and S.N. Tsyranov, Generation of powerful microwave voltage oscillations in a diffused silicon diode, Semiconductors 47(5), 670-678 (2013).

[5] R.L. Johnston, D.L. Scharfetter, and D.L. Bartelink, High-efficiency oscillations in germanium avalanche diodes below the transit-time frequency, Proc. IEEE 56(9), 1611-1613 (1968). 
[6] A.S. Clorfeine, R.J. Ikola, and L.S. Napoli, A theory for the high-efficiency mode of oscillation in avalanche diodes, RCA Review 30(3), 394-421 (1969)

[7] B.C. De Loach and D.L. Scharfetter, Device physics of TRAPATT oscillators, IEEE Trans. Electron Dev. 17(1), 9-21 (1970).

[8] R.S. Ying and N.B. Kramer, X-band silicon TRAPATT diodes, Proc. IEEE 58(8), 1285-1286 (1970).

[9] C.H. Oxley, A.M. Howard, and J.J. Purcell, X-band TRAPATT amplifiers, Electron. Lett. 13(14), 416417 (1977).

[10] K.K.N. Chang, H. Kawamoto, H.J. Prager, J. Reynolds, A. Rosen, and V.A. Milkinas, High-efficiency avalanche diodes (TRAPATT) for phased-array radar systems, in: International Solid-State Circuits Conference: Digest of Technical Papers (1973) pp. 122-123, 207.

[11] H. Kawamoto, Gigaherts-rate $100-\mathrm{V}$ pulse generator, IEEE J. Solid State Circ. 8(1), 63-66 (1973).

[12]F.K. Vaitiekūnas, J.B. Vyšniauskas, Š.A. Kamaldinov, M.J. Filatov, and G.E. Šimènas, Investigation of the pulse generator external circuit with TRAPATT diode, Tekhnika Sredstv Svyazi. Ser. Radioizmeritel'naya Tekhnika 35(1), 11-16 (1981) [in Russian].

[13]J. Vyšniauskas. Charge Generation and Transport in TRAPATT Structures during the Generation of Nonsinusoidal Oscillation, Doctoral Thesis (Vilnius University, Vilnius, 1985) [in Russian].

[14] R.A. Kiehl and R.E. Hibray, High-speed digital microwave transmitter utilizing optical modulation, Proc. IEEE 66(6), 708-709 (1978).

[15]H. Gottstein, Amplification and transformation of optical signals with a TRAPATT diode, Int. J. Electron. 56(5), 663-668 (1984).

[16] G. Šimènas. Generation of Pulsed and Sinusoidal Oscillation on Avalanche Diodes with Optical Generated Carriers, Doctoral Thesis (Vilnius University, Vilnius, 1991) [in Russian].

[17]J. Vyšniauskas and J. Matukas, Simulation of silicon $\mathrm{n}^{+} \mathrm{np}^{+}, \mathrm{p}^{+} \mathrm{pn}^{+}$and Schottky TRAPATT diodes, Lith. J. Phys. 54(2), 80-88 (2014).

[18]F.K. Vaitiekūnas, J.B. Vyšniauskas, and M.V. Meilūnas, Influence of $\mathrm{N}^{+} \mathrm{N}$ region steepness to plasma formation and extraction processes in silicon TRAPATT diodes, Elektronnaya Tekhnika, Ser. Elektronika SVCh 361(1), 34-37 (1984) [in Russian].

[19]J. Vyšniauskas, V. Klimenko, J. Matukas, and V. Palenskis. Simulation of electron diffusion effect on plasma formation in silicon TRAPATT diodes, Lith. J. Phys. 52(3), 203-213 (2012).

[20]R.A. Kiehl. Dynamic minority-carrier storage in TRAPATT diodes, Solid State Electron. 23(3), 217-222 (1980).

[21] F. Vaitiekunas and J. Vyshniauskas, Differences of plasma formation and extraction in $\mathrm{P}^{+} \mathrm{NN}^{+}$and
$\mathrm{N}^{+} \mathrm{PP}^{+}$silicon TRAPATT structures, Electron. Lett. 17(21), 822-824 (1981).

[22] D.J. Roulston, N.D. Arora, and S.G. Chamberlain, Modeling and measurement of minority-carrier lifetime versus doping in diffused layers of $n^{+}-p$ silicon diodes, IEEE Trans. Electron Dev. 29(2), 284-291 (1982).

[23] A. Schenk, A model for the field and temperature dependence of Shockley-Read-Hall lifetimes in silicon, Solid State Electron. 35(11), 1585-1596 (1992).

[24] L. Huldt, N.G. Nilsson, and K.G. Svantesson, The temperature dependence of band-to-band Auger recombination in silicon, Appl. Phys. Lett. 35(10), 776-777 (1979).

[25]W. Lochmann and A. Haug, Phonon-assisted Auger recombination in $\mathrm{Si}$ with direct calculation of the overlap integrals, Solid State Commun. 35(7), 553-556 (1980).

[26] R. Häcker and A. Hangleiter, Intrinsic upper limits of the carrier lifetime in silicon, J. Appl. Phys. 75(11), 7570-7572 (1994).

[27] A. Schenk, Rigorous theory and simplified model of the band-to-band tunneling in silicon, Solid State Electron. 36(1), 19-34 (1993).

[28] J.W. Slotboom and H.C. de Graaff, Measurements of bandgap narrowing in Si bipolar transistors, Solid State Electron. 19(10), 857-862 (1976).

[29] J.W. Slotboom and H.C. de Graaff, Bandgap narrowing in silicon bipolar transistors, IEEE Trans. Electron Dev. 24(8), 1123-1125 (1977).

[30] J.W. Slotboom, The pn-product in silicon, Solid State Electron. 20(4), 279-283 (1977).

[31] D.B.M. Klaassen, J.W. Slotboom, and H.C. de Graaff, Unified apparent bandgap narrowing in $\mathrm{n}$ - and p-type silicon, Solid State Electron. 35(2), 125-129 (1992).

[32]R. van Overstraeten and H. de Man, Measurement of the ionization rates in diffused silicon $p-n$ junctions, Solid State Electron. 13(1), 583-608 (1970).

[33]G. Masetti, M. Severi, and S. Solmi, Modeling of carrier mobility against carrier concentration in arsenic-, phosphorus-, and boron-doped silicon, IEEE Trans. Electron Dev. 30(7), 764-769 (1983).

[34] N.D. Arora, J.R. Hauser, and D.J. Roulston, Electron and hole mobilities in silicon as a function of concentration and temperature, IEEE Trans. Electron Dev. 29(2), 292-295 (1982).

[35] S.C. Choo, Theory of a forward-biased diffusedjunction P-L-N rectifier-Part I: Exact numerical solutions, IEEE Trans. Electron Dev. 19(8), $954-$ 966 (1972).

[36]N.H. Fletcher, The high current limit for semiconductor junction devices, Proc. IRE 45(6), 862-872 (1957).

[37] C. Canali, G. Majni, R. Minder, and G. Ottaviani, Electron and hole drift velocity measurements in silicon and their empirical relation to electric 
field and temperature, IEEE Trans. Electron Dev. 22(11), 1045-1047 (1975).

[38] J.J. Barnes, R.J. Lomax, and G.I. Haddad, Finiteelement simulation of GaAs MESFET's with lateral doping profiles and submicron gates, IEEE Trans. Electron Dev. 23(9), 1042-1048 (1976).

\title{
Si IR GaAs SUBMIKRONINIŲ TRAPATT DIODŲ MODELIAVIMAS
}

\author{
J. Vyšniauskas, J. Matukas \\ Vilniaus universiteto Fizikos fakultetas, Vilnius, Lietuva
}

\section{Santrauka}

Darbe pateikti plazmos susidarymo ir išsiurbimo procesų submikroniniuose silicio $\mathrm{N}^{+} \mathrm{NP}^{+}, \mathrm{GaAs} \mathrm{N}^{+} \mathrm{NP}^{+}$ ir GaAs NM Šotki TRAPATT (TRApped Plasma Avalanche Triggered Transit) dioduose modeliavimo rezultatai. GaAs TRAPATT diodai modeliuoti pirmą kartą. Procesų modeliavimui pasirinktas kvazi-hidrodinaminis modelis. Naudotas Synopsys TCAD Sentaurus programų paketas. Ivertinta krūvininkų judrio priklausomybe் nuo sklaidos fononais, priemaišinès sklaidos, krūvininkų-krūvininkų sklaidos, tarpslèninès sklaidos galio arsenide, taip pat ịvertintas judrio issisotinimas stipriame elektriniame lauke. Iskaityta keletas generacijos-rekombinacijos mechanizmų: smūginè jonizacija, Šoklio-Rido-Holo rekombinacija (SRH) su priklausančia nuo priemaišų krūvininkų gyvavimo trukme, tuneliavimas per gaudykles, tuneliavimas zona-zona, Ožè rekombinacija, spinduliuojamoji rekombinacija galio arsenide. Parodyta, kad plazmos formavimosi krizinès srovès tankis submikroniniuose dioduose dideja mažinant aktyviojo sluoksnio storị ir beveik nepriklauso nuo priemaišu tankio tame sluoksnyje. Silicio diodu krizinès srovès tankis apie du kartus mažesnis negu galio arsenido diodų. Intensyvus šalutinių krūvininkų kaupimas $\mathrm{N}^{+}$ir $\mathrm{P}^{+}$srityse stipriai veikia ịtampos virpesių amplitudę bei dažnị po pirmojo plazmos susidarymo ir išsiurbimo periodo. Virpesiai slopsta $\mathrm{N}^{+} \mathrm{NP}^{+} \mathrm{GaAs}$ dioduose su aktyviosios srities storiu, mažesniu nei $0,3 \mu \mathrm{m}$. 